\section{Large-scale Micropropagation of Aloe vera}

\author{
Enio Tiago de Oliveira ${ }^{1}$ and Otto Jesu Crocomo \\ ESALQ/USP, Biological Science, Av. Pádua Dias, 11, Piracicaba, São Paulo \\ 13418-900 PB09, Brazil
}

\section{Tatiana Bistaco Farinha}

Depto. de Ciências Biológicas, Laboratório de Controle Hormonal do Desenvolvimento Vegetal, Escola Superior de Agricultura Luis de Queiroz, ESALQ/USP, C.P. 9, 13418-900, Piracicaba, SP, Brazil

\section{Luiz Antônio Gallo}

Depto. de Ciências Biológicas, Laboratório de Biotecnologia Agrícola (CEBTEC), Escola Superior de Agricultura Luis de Queiroz, ESALQ/USP, C.P. 9, 13418-900, Piracicaba, SP, Brazil

Additional index words. Aloe, plant tissue culture, disinfection, organogenesis, plant micropropagation

\begin{abstract}
A protocol for large-scale Aloe vera (L.) Burm. f. production was established using micropropagation of apical buds. The effects of two chlorine-based disinfectants were evaluated on the survival of the explants in different treatments in a semisolidified Murashige and Skoog (MS) medium in the presence of 6-benzylaminopurine (6-BAP; 2 $\left.\mathrm{mg} \cdot \mathrm{L}^{-1}\right)$. During 120 days, 136 green apical shoots bearing axillary buds were multiplied four times at 30-day intervals in the same MS medium, reinoculating seven to nine explants per flask each time. The elongation and rooting processes were carried out in the same MS medium without 6-BAP. A total of 40,495 Aloe vera microplants were obtained, a yield of 300 microplants per apical bud at a rate of 1:5.3 in every multiplication period of 30 days. From that total, 38,480 Aloe vera microplants were successfully acclimatized transferring to 36- and 64-cell polyethylene trays containing proper substrate in two different ex vitro greenhouse conditions. After a 3-month period, fresh and dry matter weights of the Aloe vera plants were determined. All the data from each experimental phase were statistically analyzed. The use of $64-$ cell $\left(40 \mathrm{~cm}^{3} /\right.$ cell) trays represented an economy of $47.37 \%$ in greenhouse space and $50 \%$ in the amount of substrate per Aloe vera plant.
\end{abstract}

Aloe vera (L.) Burm. f., belonging to the family Asphodelaceae (Souza and Lorenzi, 2005), is one of a few Aloe species that has been explored by pharmaceutical and cosmetics industries (Mapp and McCarthy, 1970; Morton, 1961). Biological activities are ascribed to the pulp gel of Aloe vera such as antivirus, antibacterium, antifungus, anticancer, wound healing, and many others (Reynolds and Dweck, 1999), the medicinal principles being phenolics and polysaccharide compounds (Okamura et al., 1996; Park et al., 1998). Those qualities have prompted industrial and commercial increase in the production of Aloe vera throughout the world. The main constraint in this production chain is to obtain healthy primary culture for a sustainable supply of the plant materials. The common practice for the reproduction of

Received for publication 18 June 2009. Accepted for publication 6 Aug. 2009.

We thank Prof. Keigo Minami, Department of Plant Production/E.S.A. "Luiz de Queiroz"/University of São Paulo, for supplying selected Aloe vera plants.

${ }^{1}$ To whom reprint requests should be addressed; e-mail etolivei@esalq.usp.br.
Aloe is conventional vegetative propagation. However, this practice should be avoided because it can also allow the propagation of diseases frequently present in the mother plants, because it happens during the conventional vegetative propagation of other plant species such banana, potatoes, strawberry, and sugarcane. This problem can be minimized using in vitro propagation of stock materials (Crocomo and Oliveira, 1995; Debergh and Read, 1991) with the objective of the production of not only healthy, but also standardized sizes of plantlets to be used in the subsequent controlled stages of the process suitable for the clonal production of Aloe vera. In this context, this article describes a complete micropropagation system involving disinfection, in vitro multiplication, rooting, and hardening followed by ex vitro acclimatization procedures used to attain that objective, thus producing thousands of Aloe vera plants.

\section{Materials and Methods}

Plant material sources. Aloe vera plants were obtained from the field collection of the Department of Plant Production of the Escola Superior de Agricultura "Luiz de Queiroz,"
University of São Paulo, Piracicaba, SP, Brazil.

Surface disinfection treatments. Four hundred eighty apical buds explants, each $\approx 1$ $\mathrm{cm}^{3}$, were isolated from young lateral shoots bearing six to nine leaves and disinfected using three different disinfection treatments $\left(\mathrm{T}_{1}, \mathrm{~T}_{2}\right.$, and $\left.\mathrm{T}_{3}\right)$ as shown in Table 1. In each treatment, the final step (Step 7) was conducted in an air sterile chamber followed by removal of the external tissue layers of the explants up to $\approx 1 \mathrm{~cm}^{3}$ and inoculated into the shoot proliferation medium (SPM) based on semisolidified Murashige and Skoog medium (Murashige and Skoog, 1962) with $2 \mathrm{mg} \cdot \mathrm{L}^{-1}$ glycine, $100 \mathrm{mg} \cdot \mathrm{L}^{-1}$ myo-inositol, $30 \mathrm{~g} \cdot \mathrm{L}^{-1}$ sucrose, and $2 \mathrm{mg} \cdot \mathrm{L}^{-1}$ 6-benzylaminopurine (6-BAP); the $\mathrm{pH}$ was adjusted to 5.8 before adding $2.3 \quad \mathrm{~g} \cdot \mathrm{L}^{-1} \quad$ Phytagel $^{\circledR} \quad$ (SIGMAALDRICH Inc., St Louis, MO). In each treatment, 160 buds were individually inoculated in $12.5 \mathrm{~cm}$ diameter $\times 8 \mathrm{~cm}$ long test tubes containing $12.5 \mathrm{~mL}$ of the SPM medium and incubated in growth room at $25^{\circ} \mathrm{C} \pm 2$ under light $\left(50 \mu \mathrm{mol} \cdot \mathrm{m}^{-2} \cdot \mathrm{s}^{-1}\right)$ with a photoperiod of $16 / 8 \mathrm{~h}$. The effect of the disinfection treatments was evaluated after $30 \mathrm{~d}$ in the culture medium taking into account the rates of explant contamination, necrosis, and green apical shoot (GAS) development.

Shoot proliferation. After $30 \mathrm{~d}$ in the SPM medium, the best 136 green apical shoot explants bearing axillary buds (GAS) were selected, longitudinally divided, and transferred from the test tubes to $350-\mathrm{mL}$ glass flasks containing $50 \mathrm{~mL}$ of the same medium and cultivated for an additional $90 \mathrm{~d}$ under the same experimental conditions with replication at 30-d intervals. Seven to nine explants were transferred in each replication.

Elongation and root induction. Developed Aloe plantlets were transferred to culture medium without 6-BAP to induce elongation and rooting for a $30-\mathrm{d}$ period.

Table 1. Sequential procedures for Aloe vera explant disinfection.

\begin{tabular}{lcccccccc}
\hline & \multicolumn{10}{c}{ Steps } \\
\cline { 2 - 8 } Treatments & 0 & 1 & 2 & 3 & 4 & 5 & 6 & 7 \\
\hline $\mathrm{T}_{1}$ & - & $\mathrm{H}$ & $\mathrm{H}$ & $\mathrm{H}$ & $\mathrm{H}$ & $\mathrm{H}$ & $\mathrm{H}$ & $\mathrm{H}$ \\
$\mathrm{T}_{2}$ & $\mathrm{H}$ & $\mathrm{S}$ & $\mathrm{S}$ & $\mathrm{S}$ & $\mathrm{H}$ & $\mathrm{H}$ & $\mathrm{H}$ & $\mathrm{H}$ \\
$\mathrm{T}_{3}$ & $\mathrm{~S}$ & $\mathrm{~S}$ & $\mathrm{H}$ & $\mathrm{S}$ & $\mathrm{S}$ & $\mathrm{H}$ & $\mathrm{H}$ & $\mathrm{H}$ \\
\hline
\end{tabular}

$\mathrm{H}=$ sodium hypochlorite $(0.5 \% \mathrm{v} / \mathrm{v}$ active chlorine $)$ solution; $\mathrm{S}=0.06 \%(\mathrm{v} / \mathrm{v})$ solution prepared from the sodium dichloroisocyanurate (Sumaveg ${ }^{\circledR}$ Unilever Brasil Ltda, São Paulo, SP) with $3 \%(\mathrm{v} / \mathrm{v})$ active chlorine solution; Step $0=$ only for $\mathrm{T}_{2}$ and $\mathrm{T}_{3}$ treatments: previous shoot washing with the respective solution; Step 1 = shoot defoliation (three to four leaves) followed by immersion into the respective solution, $\approx 30$ minutes; Step $2=$ shoot defoliation of the remaining leaves followed by immersion into the respective solution, $\approx 30$ minutes; Step 3 = rinsing with the respective solution; Step $4=$ resting with the respective solution, $\approx 2 \mathrm{~h}$; Step $5=$ rinsing with the respective solution; Step $6=$ rinsing with the respective solution prepared with sterile water; Step 7 = final disinfection by immersion into the respective solution prepared with sterile water for 30 minutes. In each treatment 160 replicates were used. 


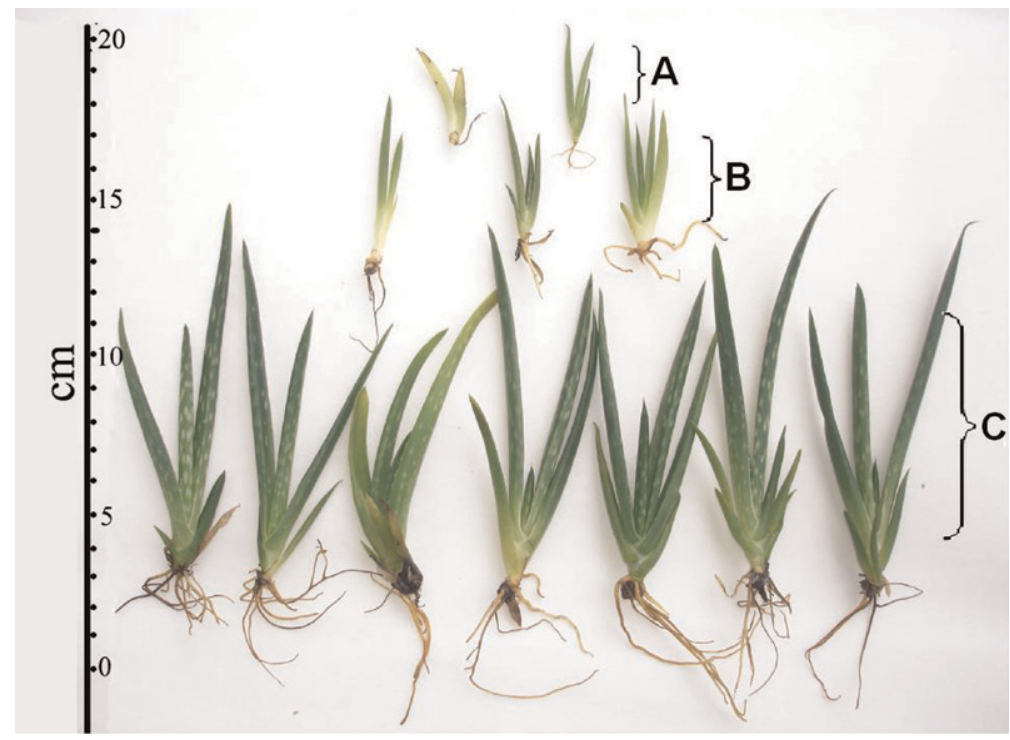

Fig. 1. Effect of the disinfection treatments on the survival of apical shoots of Aloe vera. Analysis was made using 480 explants.

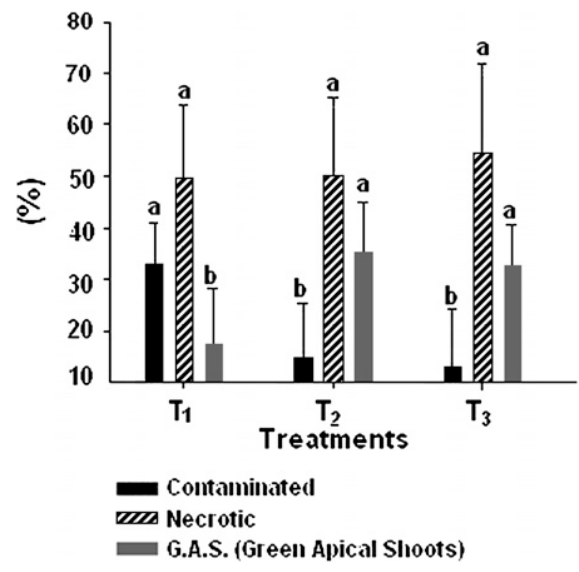

Fig. 2. Classification of Aloe vera microplants by size: (A) Small size $\left(\mathrm{M}_{\mathrm{s}}\right)$. (B) Medium size $\left(\mathrm{M}_{\mathrm{m}}\right)$. (C) large size $\left(\mathrm{M}_{1}\right)$.

Hardening and acclimatization. The average rate of Aloe microplant production was evaluated following the in vitro proliferation; 38,480 microplants were used in the hardening and acclimatization processes. The microplants were classified as: small $\left(\mathrm{M}_{\mathrm{s}}\right), 3$ to $4 \mathrm{~cm}$ long bearing two to three leaves; medium $\left(\mathrm{M}_{\mathrm{m}}\right), 6$ to $8 \mathrm{~cm}$ long bearing four to five leaves; and large $\left(\mathrm{M}_{1}\right), 13$ to $16 \mathrm{~cm}$ long bearing five to seven leaves (Fig. 1). The microplants were transferred to two different types of black polyethylene trays labeled $\mathrm{B}_{1}$ $\left(80 \mathrm{~cm}^{3} /\right.$ cell $)$ and $\mathrm{B}_{2}\left(40 \mathrm{~cm}^{3} /\right.$ cell $)$ with 36 and 64 cells each, respectively. The trays were maintained in two different types of greenhouses with automatically controlled relative humidity and proper irrigation namely: $\mathrm{G}_{1}$, pad-house system using microaspersion irrigation and air exhaustion; and $\mathrm{G}_{2}$, conventional greenhouse using nebulization and forced air ventilation. A mixture of bark pinus, vermiculite, sand, and fertilizers (Terra do Paraiso $^{\mathrm{TM}}$; Substratos Agrícolas Ltda, Holambra, SP), $\mathrm{pH} 6.04$ and electric conductivity ence. The Tukey test was used for hardening and acclimatization, comparing microplant sizes $\times$ tray types $\times$ greenhouse conditions.

\section{Results and Discussion}

Disinfection, shoot differentiation, and rooting. The three disinfection treatments were effective in different degrees for disinfecting the Aloe vera apical buds in vitro. The statistical analysis of the effect of the disinfection processes on the rates of contamination, mainly by bacteria, and on the green apical shoots with axillary buds (GAS) production (Fig. 2) showed no significant differences $(P>0.05)$ between $\mathrm{T}_{2}$ and $\mathrm{T}_{3}$ treatments, both being different from $\mathrm{T}_{1}$ $(P<0.05)$. In relation to the contamination and the GAS rates, the best results were obtained by $\mathrm{T}_{3}(13.12 \%$ for contamination and $32.50 \% \mathrm{GAS})$ and $\mathrm{T}_{2}(15 \%$ for contamination and $35 \%$ for GAS) and $\mathrm{T}_{1}(32.81 \%$ for contamination and $17.50 \%$ for GAS). This was attributable mainly to washing the start material in the disinfectant solutions at the beginning of the process (Step S0 or H0). In regard to necrosis of the explants (Fig. 2), no significant differences were observed among the three treatments: $\mathrm{T}_{1}, 49.69 \% ; \mathrm{T}_{2}$, $50.00 \%$; and $\mathrm{T}_{3}, 54.38 \%$.

The degrees of injury on the explants depend on the type of disinfection processes and the nature of the plant material. The Aloe vera tissue has low lignin content and is very sensitive to disinfectants. This is not likely to be the result of chlorine toxicity, either of the hypochlorite or the sodium dichlorisocyanurate, which is largely used to disinfect "freshcut" products (Lund et al., 2005). One can assume that this could be attributed to the alkalinity of the disinfectant solutions. This aggressiveness was observed mainly in the rates of necrosis of the explants.

From 480 inoculated explants, 136 green apical shoots with axillary buds (GAS) were multiplied three times at 30-d intervals in the same SPM medium. The shoots were longitudinally divided and seven to nine explants were reinoculated per flask in the same culture medium each time.

After the stage of multiplication, the plantlets were separated and transferred to the previous culture medium without 6-BAP to induce elongation and rooting. At the end of the multiplication and rooting periods, 
Table 3. Effect of acclimatization conditions on the increase of dry matter weight $(\mathrm{g})$ of Aloe vera microplants.

\begin{tabular}{|c|c|c|c|c|}
\hline \multirow[b]{2}{*}{ Microplants } & \multicolumn{2}{|c|}{ Greenhouse $1\left(\mathrm{G}_{1}\right)$} & \multicolumn{2}{|c|}{ Greenhouse $2\left(\mathrm{G}_{2}\right)$} \\
\hline & Tray $1\left(\mathrm{~B}_{1}\right)$ & Tray $2\left(\mathrm{~B}_{2}\right)$ & Tray $1\left(B_{1}\right)$ & Tray $2\left(B_{2}\right)$ \\
\hline$\overline{\mathrm{M}_{\mathrm{s}}}$ & $0.20 \mathrm{aA}^{*}$ & $0.16 \mathrm{aA}^{*}$ & $0.18 \mathrm{aA}^{*}$ & $0.15 \mathrm{aA}^{*}$ \\
\hline $\mathrm{M}_{\mathrm{m}}$ & $0.29 \mathrm{aA}^{*}$ & $0.24 \mathrm{aA}^{* \dagger}$ & $0.35 \mathrm{aA} \dagger$ & $0.21 \mathrm{aA}^{*}$ \\
\hline $\mathrm{M}_{1}$ & $0.60 \mathrm{aA} \dagger$ & $0.38 \mathrm{bA} \uparrow$ & $0.48 \mathrm{aA} \dagger$ & $0.39 \mathrm{aA} \dagger$ \\
\hline
\end{tabular}

Averages followed by at least the same letter or symbol did not differ among them by the Tukey test $(P<$ 0.05). Lower case letters: comparison for trays (constant microplants and greenhouse). Upper case letters: comparison for greenhouses (constant microplants and trays). Symbols $(* \dagger)$ : comparison in the same column for microplant size (constant tray and greenhouse).

$\mathrm{M}_{\mathrm{s}}=$ Small size microplants; $\mathrm{M}_{\mathrm{m}}=$ medium size microplants; $\mathrm{M}_{1}=$ large size microplants; $\mathrm{G}_{1}=$ greenhouse with pad-house and microaspersion irrigation; $\mathrm{G}_{2}=$ greenhouse with nebulization irrigation and forced air $\mathrm{B}_{1}=36$-cell trays $\left(80 \mathrm{~cm}^{3} / \mathrm{cell}\right) ; \mathrm{B}_{2}=64$-cell trays $\left(40 \mathrm{~cm}^{3} / \mathrm{cell}\right)$. Each value is the average of 10 replicates.

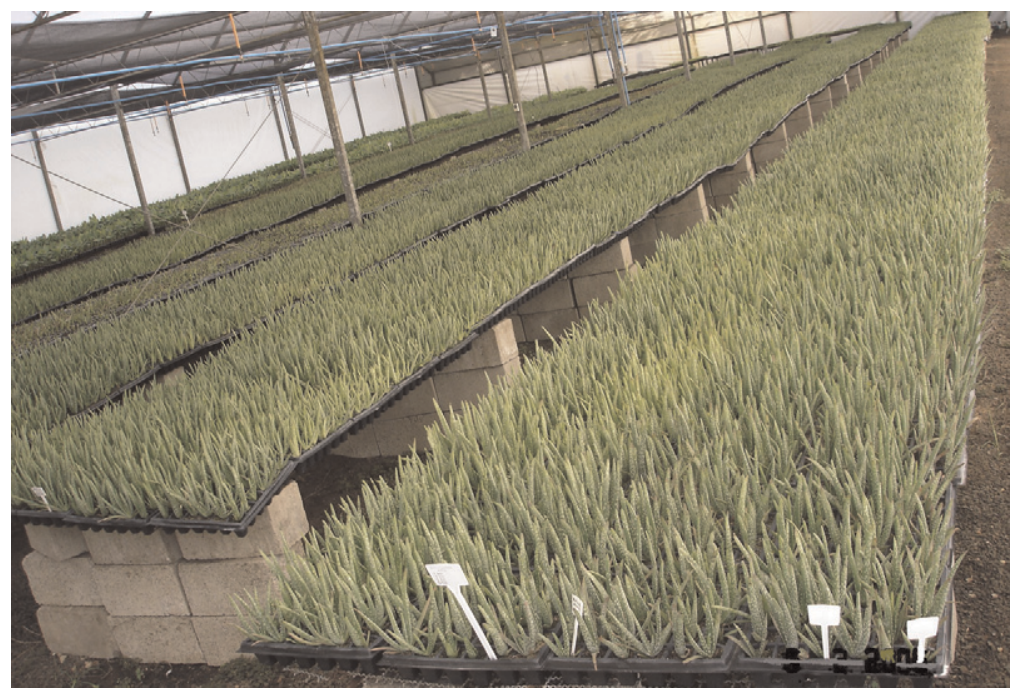

Fig. 4. General view of Aloe vera microplants acclimatization in pad-house system greenhouse with microaspersion irrigation $\left(\mathrm{G}_{1}\right)$. A total of $800 \mathrm{~m}^{2}$ was suitable for 3330 trays.

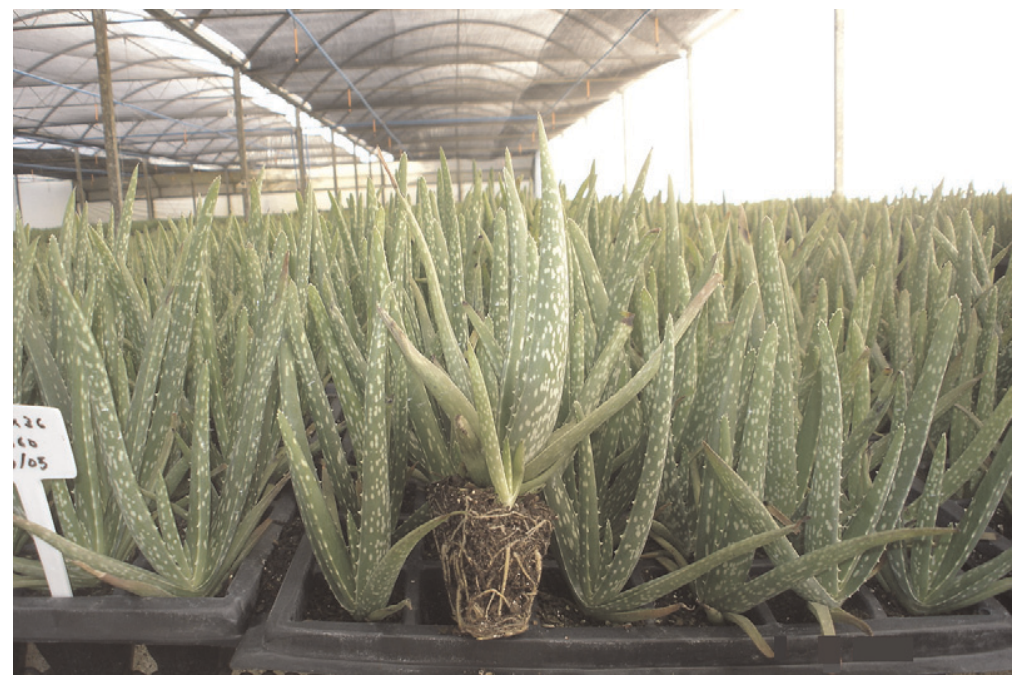

Fig. 5. Aloe vera microplants: 3 months acclimatization in a pad-house system greenhouse with microaspersion irrigation $\left(\mathrm{G}_{1}\right)$.

40,495 Aloe vera plantlets were obtained, representing a yield of 300 microplants per apical shoot, or a rate of 1:5.3 in every multiplying period of $30 \mathrm{~d}$.

Similar results were observed by Marfori and Malasa (2005) testing the effects of 6BAP and kinetin on Aloe vera development obtained ratios varying from $1: 2$ up to $1: 8$, depending on the genotype, using $1.5 \mathrm{mg} \cdot \mathrm{L}^{-1}$ 6-BAP and $0.75 \mathrm{mg} \cdot \mathrm{L}^{-1} \mathrm{NAA}$ in the in vitro multiplication of 16 different Aloe vera genotypes.

Hardening and acclimatization. After a period of 3 months of acclimatization, the rate of microplant survival and their fresh and dry matter contents were determined. In terms of rate of microplant survival, there was a statistically significant difference $(P<$ 0.05 ) observed only in size difference. No other factor such as greenhouse type and tray type, nor their interactions, showed significant differences $(P>0.05)$. As far as size is concerned, medium $\left(\mathrm{M}_{\mathrm{m}}\right)$ and large $\left(\mathrm{M}_{\mathrm{l}}\right)$ were found to be significantly different from small $\left(\mathrm{M}_{\mathrm{s}}\right)$ microplants $(P<0.05)$ (Fig. 3).

The statistical analysis showed a positive interaction among the rate of survival, the content of fresh matter weight (FW), and dry matter weight (DW) $(P<0.05)$ during acclimatization. Tables 2 and 3 show the data for FW and DW for the three microplant sizes, respectively. Fresh matter weight content was higher in large microplants $\left(\mathrm{M}_{1}\right)$ maintained in 36-cell trays under microaspersion $\left(G_{1}\right)$ than in the other sizes and also higher than in the $\mathrm{M}_{1}$ microplants maintained under nebulization in 36- or 64-cell trays. Figure 4 shows a general view of the Aloe vera microplant acclimatization under microaspersion irrigation in a $800-\mathrm{m}^{2}$ greenhouse with a padhouse system suitable for 3300 trays. Figure 5 shows large Aloe vera microplants $\left(\mathrm{M}_{1}\right)$ after 3 months of acclimatization. Considering that number of cells in the trays showed no influence on the rate of microplants survival and FW and DW content, the choice of the number of cells is a practical one: using 64cell trays $\left(40 \mathrm{~cm}^{3} /\right.$ cell $)$, there is an economy of $47.37 \%$ in greenhouse space and $50 \%$ in the amount of substrate used per microplant.

\section{Conclusions}

At least 300 microplants were produced from a single apical bud of Aloe vera in a period of 4 months. The best results of the apical shoot disinfection were obtained when the field-harvested Aloe vera stocks were previously rinsed with a solution either of sodium hypochlorite or sodium dichloroisocyanurate.

The Aloe vera plantlets were successfully ex vitro acclimatized in a greenhouse bearing a pad-house system with microaspersion and air exhaustion using $36-\left(80 \mathrm{~cm}^{3} /\right.$ cell $)$ or 64 $\left(40 \mathrm{~cm}^{3} /\right.$ cell) cell polyethylene trays containing the proper substrate. Because the cell number in the trays showed no influence either on the survival of the plants or on the FW and DW, the use of 64-cell $\left(40 \mathrm{~cm}^{3} /\right.$ cell) trays represents an economy of $47.37 \%$ in substrate per Aloe vera plant. greenhouse space and $50 \%$ in the amount of

\section{Literature Cited} obtained a ratio of $1: 15$ for the micropropagation of chinese Aloe in the presence of $2 \mathrm{mg} \cdot \mathrm{L}^{-1}$ 6-BAP plus $0.3 \mathrm{mg} \cdot \mathrm{L}^{-1}$ naphthalene-acetic acid (NAA). Araújo et al. (2002)

in vitro; in the presence of $2.3 \mathrm{mg} \cdot \mathrm{L}^{-1} 6$-BAP, the ratio was $1: 11.3$ and in the presence of 1 $\mathrm{mg} \cdot \mathrm{L}^{-1} 6$-BAP, it was $1: 9$. Liao et al. (2004) Araújo, P.S., J.M.O.D. Silva, C.A. Nechel, C.
Ianssem, A.C. Oltramari, R. Passos, E. Tiepo, 
D.B. Bach, and M. Maraschin. 2002. Micropropagação de babosa (Aloe vera-Liliaceae). Biotecnologia Ciência e Desenvolvimento, Brasília, No. 25, p. 54-57.

Crocomo, O.J. and E.T. Oliveira. 1995. Biotecnologia de plantas como um programa de produção vegetal. In: Gerald, L.T.S. (ed.). Biofábrica Produção Industrial de Plantas 'In Vitro'. Araras: UFSCar. p. 18-21.

Debergh, P.C. and P.E. Read. 1991. Micropropagation, p. 1-13. In: Debergh, P.C. and R.H. Zimmerman (eds.). MicropropagtionTechnology and application. Kluwer Academic Publishers, Dordrecht, The Netherlands.

Liao, Z., M. Chen, F. Tan, X. Sun, and K. Tang. 2004. Micropropagation of endangered Chinese aloe. Plant Cell, Tissue and Organ Culture 76:83-86.
Lund, D.G., L.A. Petrini, J.A.G. Aleixo, and C.V. Rombaldi. 2005. Uso de sanitizantes na redução da carga microbiana de mandioca minimamente processada. Ciência Rural, Santa Maria, 35(6):1431-1435.

Mapp, R.K. and T.J. McCarthy. 1970. The assessment of purgative principles in Aloes. Planta Medica, New York 18:361-365.

Marfori, E.C. and A.B. Malasa. 2005. Tissue culture for rapid clonal propagation of Aloe barbadensis Miller. Philippine Agricultural Scientist, Laguna 88:167-170.

Morton, J.F. 1961. Folk Uses and commercial exploitation of Aloe leaf pulp. Economic botany Bronx 15:311-319.

Murashige, T. and F. Skoog. 1962. A revised medium for rapid growth and bioassays with tobacco tissue cultures. Physiologia Plantarum, Copenhagen 15:473-497.
Okamura, N., M. Asai, N. Hine, and A. Yagi. 1996. High-performance liquid chromatographic determination of phenolic compounds in Aloe species. J. Chromatography 746: 225-231.

Park, M.K., J.H. Park, N.Y. Kim, Y.G. Shin, Y.S. Choi, J.G. Lee, K.H. Kim, and S.K. Lee. 1998. Analysis of 13 phenolic compounds in Aloe species by high performance liquid chromatography. Phytochemical Analysis Sussex 9:186-191.

Reynolds, T. and A.C. Dweck. 1999. Aloe vera leaf gel: A review update. Journal of Ethnopharmacology, Lausanne 68:3-37.

Souza, V. and H. Lorenzi. 2005. Botânica Sistemática: Guia ilustrado para identificação das famílias de Angiospermas da flora brasileira, baseado em APG II. Instituto Plantarum, Nova Odessa, 640 p. 